\title{
A highly sensitive detection for foot-and-mouth disease virus by gold nanopariticle improved immuno-PCR
}

Yao-zhong Ding ${ }^{1 \dagger}$, Yong-sheng Liư ${ }^{1 \dagger}$, Jian-hua Zhou', Hao-tai Chen', Gang Wei², Li-na Ma and Jie Zhang

\begin{abstract}
Backgroud: Foot-and-mouth disease (FMD) is one of the most contagious of all artiodactyl animal diseases, and its infection has an obvious ability to spread over long distances and to contribute to epidemics in FMD-free areas. A highly sensitive and specific method is required to detect FMDV. In this study, we evaluated the usefulness of a bio-barcode assay (BCA) technique for detecting clinical samples of FMDV.

Methods: Highly sensitive gold nanopariticle (GNP) improved immuno-PCR (GNP-IPCR) which derived from the bio-barcode assay (BCA) was designed for the detection of FMDV. The target viral particles were captured by a polyclonal antibody coated on ELISA microplate, followed by adding GNP which was dually modified with oligonucleotides and a FMDV specific monoclonal antibody (MAb) 1 D11 to form a sandwiched immune complex. After the formation of immuno-complex, the signal DNA was released by heating, and consequently characterized by PCR and real time PCR.

Results: The detection limit of GNP-PCR could reach to $10 \mathrm{fg} / \mathrm{ml}$ purified FMDV particles, and the assay can detect clinical samples of FMDV with highly sensitivity, while detect limit of conventional ELISA is $100 \mathrm{ng} / \mathrm{ml}$ in this study.

Conclusion: GNP-IPCR may provide a highly sensitive method for the detection of FMDV.
\end{abstract}

\section{Backgroud}

Foot-and-mouth disease virus (FMDV), which belongs to the Aphthovirus genus of the family Picornaviridae, is a single-stranded positive sense RNA virus of $8,500 \mathrm{bp}$ and is enclosed by an icosahedral capsid [1]. The virus exists as seven serologically distinct types $(\mathrm{O}, \mathrm{A}, \mathrm{C}$, Asia 1 , SATs $1,2,3)$ [2]. The virus affects artiodactyl, especially cattle and swine, and FMD is one of the most contagious of all animal diseases. In 2001, outbreaks of FMD in Taiwan, South Korea and the United Kingdom resulted in the slaughter of millions of animals and huge economic losses [3]. This virus can survive in meat and other animal products for a long periods [4], and FMD is endemic in large area of South America, Asia, Africa, and its infection has an obvious ability to spread over long distances and to cause epidemics in FMD-free areas.

\footnotetext{
* Correspondence: scarlettezhang@yahoo.com.cn

+ Contributed equally

Full list of author information is available at the end of the article
}

Many methods have been developed to detect the FMDV, such as ELISA [5], hybridization assays [6], conventional RT-PCR [7] and real-time RT -PCR [8-14]. Generally, the sensitivity of ELISA is lower, but which can detect antigens or antibodies. The sensitivity of PCR is higher, but it can only detect DNA/RNA of the virus, and can also lead to false-positive results. 朗读.

Recently, a new highly sensitive assay, namely bio-barcode amplification (BCA) assay, was developed for ultrasensitive detection of target proteins and nucleic acids, the detection limit could reach the level of 30 attomolar (aM) [15-17]. BCA combines the advantages of both ELISA and PCR, it has not only the sensitivity of PCR, but also can detect the antigens or antibodies. In the BCA, gold nanoparticles (GNPs) could conjugate with DNA and specific monoclonal antibody (Mab). Many DNA immobilized on the surface of GNP would further improve the sensitivity of conventional immuno-PCR $[18,19]$. In this study, the application of BCA was evaluated for detecting clinical FMD samples.
C Biomed Central

() 2011 Ding et al; licensee BioMed Central Ltd. This is an Open Access article distributed under the terms of the Creative Commons Attribution License (http://creativecommons.org/licenses/by/2.0), which permits unrestricted use, distribution, and reproduction in any medium, provided the original work is properly cited. 


\section{Materials and methods Cells and virus}

BHK-21 cells were grown in MEM medium (Qingdatianyi Co., China) containing $4 \%$ newborn calf serum (PPA, Australia), and used to replicate FMDV. FMDV strain China/99 specific MAb 1D11 and the polyclonal antibody rabbit sera against the FMDV type $\mathrm{O}$ used in this study were provided by our laboratory.

Real MasterMix (SYBR GREEN) kit was provided by TaKaRa Biotechnology Co., Ltd. (Dalian, China) and rabbit anti-guinea pig IgG which was conjugated with horseradish peroxidase (HRP) was provided by Sigma (Sigma, US).

GNPs with an average diameter of $30 \mathrm{~nm}$ were obtained from Ted Pella Inc (CA, USA). All oligonucleotides and primers were synthesized from Sangon Co., Ltd. (Shanghai, China) (Table 1).

\section{Preparation of bi-functionalized GNP conjugated with oligonucleotides and monoclonal antibodies}

GNPs bi-functionalized with MAb 1D11 and the conjugation DNA were prepared as reported previously [15]. First, the primary gold nanoparticles solution was adjusted to $\mathrm{pH} 9.2$ with $1 \mathrm{M} \mathrm{NaOH}$. Then, $1 \mathrm{ml}$ of the solution was mixed with $6 \mu \mathrm{g}$ MAb 1D11 at room temperature and was mildly shaking for $30 \mathrm{~min}$. This solution was added with 1 OD thiolated conjunction DNA for $16 \mathrm{~h}$ at $10^{\circ} \mathrm{C}$. Then, a procedure of salt-aging was carried out by adding $2 \mathrm{M} \mathrm{NaCl}$ in a six-stepwise-addition within $24 \mathrm{~h}$ to this solution in order to make $0.1 \mathrm{M}$ of the final concentration of $\mathrm{NaCl} .0 .3 \mathrm{ml}$ of a $10 \%$ bovine serum albumin (BSA) solution was added into the solution with extensive incubation at room temperature for $30 \mathrm{~min}$ to stabilize and achieve passivation of GNPs. The solution was centrifuged at $4^{\circ} \mathrm{C}$ for $20 \mathrm{~min}$, and the supernatant was removed. The nanoparticles were resuspended in $0.1 \mathrm{M}$ phosphate buffered solution (PBS, pH7.4) and centrifuged again in order to achieve further purification of nanoparticles. The nanopaticles were resuspended in the $400 \mu \mathrm{l}$ PBS with $1 \mathrm{OD}$ of the signal DNA and hybridized at $37^{\circ} \mathrm{C}$ for $1 \mathrm{~h}$. The similar centrifugation procedure was performed to remove the redundant signal DNA and obtain the bi-functionalized GNPs. Finally, the probes were resuspended in PBS with
$0.01 \%$ Tween-20 (v/v) and 0.1\% BSA (w/v). This bi-funtionalized GNPs probes solution was stored at $4^{\circ} \mathrm{C}$.

\section{Assay for FMDV by ELISA}

Conventional ELISA was performed as reported previously [20]. Each microplate (Corning Costar Inc., US) were coated with polyconal antibody $(10 \mu \mathrm{g} / \mathrm{ml})$ in $0.1 \mathrm{M}$ carbonate/bicarbonate buffer ( $\mathrm{pH} 9.4)$ overnight at $4^{\circ} \mathrm{C}$. Plates were blocked with 5\% skim milk in PBS and washed three times with PBST (containing 0.1\% Tween-20, pH7.4). After three times of washing, each microplate was added with $50 \mu \mathrm{l}$ of tenfold serial dilutions of the purified FMDV ( $1 \mathrm{ug} / \mathrm{ml}$ to $0.1 \mathrm{pg} / \mathrm{ml}$ ) incubated for $1 \mathrm{~h}$ at $37^{\circ} \mathrm{C}$. The plates were subsequently washed, then $50 \mu \mathrm{MAb} 1 \mathrm{D} 11$ (1:1000 dilution) was added and incubated for $1 \mathrm{~h}$ at $37^{\circ} \mathrm{C}$. After three washings, $50 \mu \mathrm{l}$ Goat anti-mouse IgG which was conjugated with horseradish peroxidase (HRP) (Sigma) was added and incubated for $1 \mathrm{~h}$ at room temperature. Three time of washing with PBST, the ELISA reaction was developed by the addition of ophenylenediamine- $\mathrm{H}_{2} \mathrm{O}_{2}$ for $20 \mathrm{~min}$ at $37^{\circ} \mathrm{C}$. The reaction was stopped by the addition of $50 \mu \mathrm{l} 1.5 \mathrm{M} \mathrm{H}_{2} \mathrm{SO}_{4}$ and the microplate was read at OD 490 by a plate reader (Bio-Rad 680, USA).

\section{Detection of FMDV by GNP probe}

All procedure of coating and blocking for GNP-IPCR were carried out by same way with the ELISA. The assay of GNP-IPCR was conducted as described previously [19]. The microplates were washed using $0.05 \mathrm{M}$ PBSET (including $5 \mathrm{mM}$ EDTA and 0.05\% Tween-20). $50 \mu \mathrm{l}$ of tenfold serial dilutions of purified FMDV $(10 \mathrm{pg} / \mathrm{ml}$ to $0.01 \mathrm{fg} / \mathrm{ml}$ ) were respectively added into the microplates and then incubated at $37^{\circ} \mathrm{C}$ for $1 \mathrm{~h}$, following by five times of washing. Then $50 \mu \mathrm{l}$ GNP probe was added into microplates and incubated for $1 \mathrm{~h}$ at $37^{\circ} \mathrm{C}$, washed five times with PBS, add $50 \mu \mathrm{l}$ of double distilled $\mathrm{H}_{2} \mathrm{O}$ into each microplates. Finally, the plates were handled in a water bath at $80^{\circ} \mathrm{C}$ for $10 \mathrm{~min}$ to release the signal DNA which is then analyzed by PCR.

PCR amplification was performed by adding $5 \mu \mathrm{l}$ of the free signal DNA as templates $(0.2 \mu \mathrm{M}$ each primers, $1 \mathrm{mM}$ dNTP, $10 \times$ buffer and $2.5 \mathrm{U}$ Taq DNA polymerase). The amplification products were analyzed by $2 \%$ agarose gel electrophoresis.

Table 1 Oligonucleotides and primer sequences used in this work

\begin{tabular}{cc}
\hline name & Sequence \\
\hline Capture DNA & SH-5'-dA15TTCATCGCCCTTGGACTACGACTCTGACTGATCGCTAAATCGTG-3' \\
Signal DNA & 5'-CACGATTAGCGATCAGTCAGAGTCGTAGTCCAAGGGCGATGAA-3' \\
F-signal DNA & FAM-5'-CACGATTAGCGATCAGTCAGAGTCGTAGTCCAAGGGCGATGAA-3' \\
Forward primer & 5'-CATCGCCCTTGGACTACGA-3' \\
Reverse primer & 5'-CACGATTAGCGATCAGTCAGAG-3' \\
\hline
\end{tabular}

${ }^{*} \mathrm{dA}_{15}$ means that there are $15 \mathrm{dA}$, and $\mathrm{SH}$ means that this end of the oligonueotide is modified by alkanthiol group. 


\section{Detection of Real-time PCR for signal DNA}

Real time PCR amplification was performed by adding 5 $\mu \mathrm{l}$ of the released signal DNA solutions as templates, added $0.5 \mu \mathrm{l}$ forward primer $(10 \mu \mathrm{M})$ and reverse primer $(10 \mu \mathrm{M})$ listed in Table 1 into the MasterMix (SYBR GREEN) kit in a total volume of $20 \mu \mathrm{l}$. The cycling parameters were an initial DNA denaturation step at $95^{\circ} \mathrm{C}$ for $30 \mathrm{sec}$ followed by 40 cycles of PCR with DNA denaturation at $95^{\circ} \mathrm{C}$ for $15 \mathrm{sec}$ and primer annealing and extension at $68^{\circ} \mathrm{C}$ for $30 \mathrm{sec}$.

\section{Detection Clinical FMDV samples using GNP-IPCR}

To evaluate whether this method is perfect for clinical FMDV sample assays, a total of 30 sera, 20 vesicle fluids of type $\mathrm{O}$ of FMDV and 26 negative sera of FMDV and 10 type Asia 1 of FMDV samples were isolated in our laboratory to be identified by GNP-IPCR.

\section{Results}

\section{Detection FMDV Antigen using GNP-IPCR and ELISA}

To compare the sensitivity and detection limit between the GNP-IPCR and ELISA, we applied both GNP-IPCR and ELISA to detect the purified FMDV antigens. As shown in Figure 1, the detection limit of ELISA is 100 $\mathrm{ng} / \mathrm{ml}$, but the detection limit of GNP-IPCR is about $10 \mathrm{fg} / \mathrm{ml}$ of FMDV purified antigens, which was 7 titers of magnitude more sensitive than general ELISA system.

\section{Detection of FMDV by GNP-IPCR real-time PCR}

Gel electrophoresis is a wildly used tool in immunoPCR to quantify the PCR amplification, but it has some shortcoming such as time consuming. Here, a SYBR green-based fluorescence quantification RT-
PCR was adopted for analysis of the released signal DNA. As shown in Figure 2, clear distinctness in signals was found between FMDV samples and the negative control. The FMDV concentration ranges from $10 \mathrm{pg} / \mathrm{ml}$ to $1 \mathrm{fg} / \mathrm{ml}$, and $1 \mathrm{fg} / \mathrm{ml}$ purified FMDV can be distinguished from the negative control by this assay.

\section{Detection FMDV Clinical samples using GNP-IPCR}

Detection of FMDV clinical sample using GNP-IPCR indicated that 30 sera, 20 vesicle fluids of type $O$ of FMDV was identified as positive, 1 negative serum identified as suspected positive may be due to the sample contamination, no cross reaction of this assay with serotype Asia 1 (Table 2). Owing to its rapidity, sensitivity and specificity, GNP-IPCR assay is suitable for clinical diagnosis and surveillance of FMDV, and the whole assay could be completed within $4 \mathrm{~h}$.

\section{Discussions}

ELISA and conventional PCR are standard laboratory assays which applied to detect FMDV [21-25]. These assays have been shown restricted on the detection of FMDV antigen [14] because the ELISA lack of the high sensitivity, and the PCR can only detect DNA/RNA 朗读. To combine the applicability for detection of antigen of ELISA and the high sensitivity of PCR, Sano et al., developed the immuno-PCR (IPCR) method [26]. This application is also limited for the lack of standards related products and difficulty of synthesis of antibodyoligonucleotides conjugation of IPCR. We are pay attention to the ability of the BCA-IPCR for detecting FMDV. This method offers an innovative approach to detect target proteins that overcomes shortcomings of

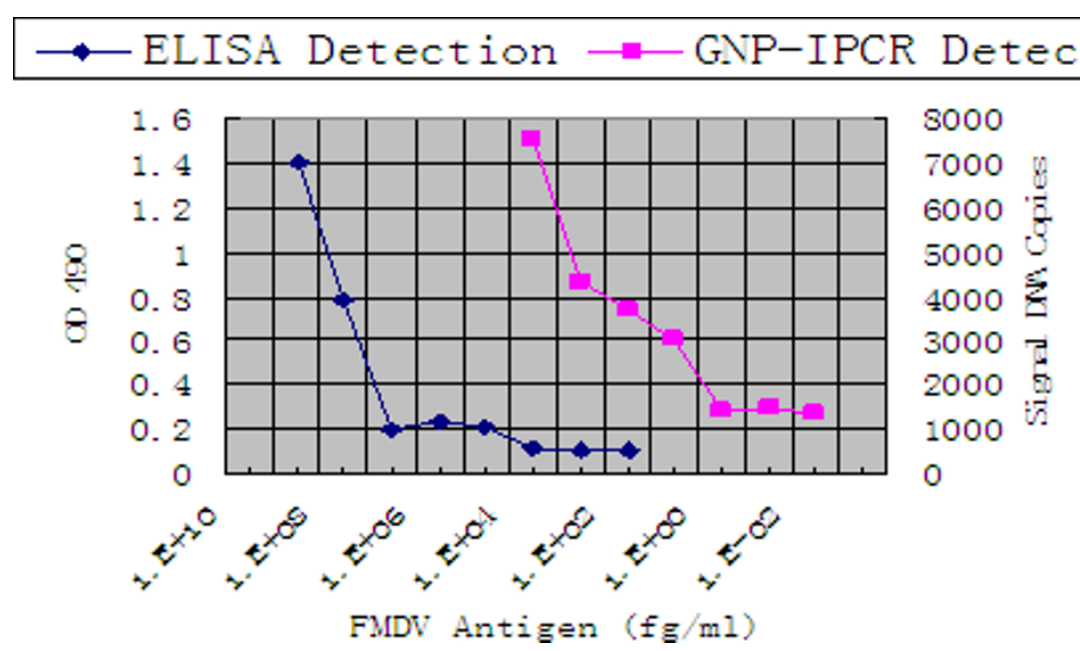

Figure 1 Detection of serial dilutions of purified FMDV using GNP-IPCR and ELISA. The detect limit of ELISA was $100 \mathrm{ng} / \mathrm{ml}$ purified FMDV and that of GNP-IPCR was $10 \mathrm{fg} / \mathrm{ml}$. 


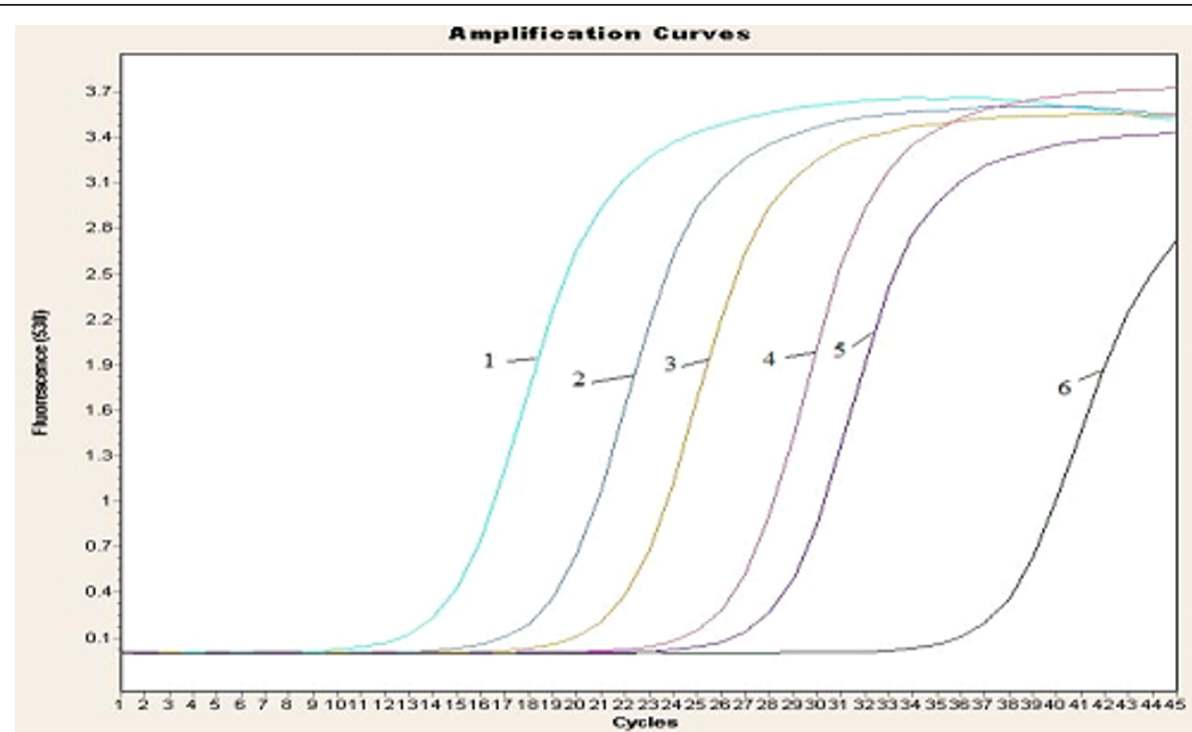

Figure 2 SYBR-GREEN real time PCR detection of FMDV based on GNP-IPCR. Curve 1-5 represents samples with FMDV concentration of $10 \mathrm{pg} / \mathrm{ml}, 1 \mathrm{pg} / \mathrm{ml}, 100 \mathrm{fg} / \mathrm{ml}, 10 \mathrm{fg} / \mathrm{ml}$ and $1 \mathrm{fg} / \mathrm{ml}$, and 6 represent negative control, respectively.

IPCR. The method is exquisitely specific because antigens or antibodies bound to GNPs and the GNPs are directed against two or more distinct epitopes [27-29], and the method is more convenient and time-saving than conventional IPCR assays [30-33].

BCA technology combines the advantages of PCR and ELISA which have a specificity and sensitivity of detection of clinical samples. The detect limit of GNP-PCR can be $10 \mathrm{fg} / \mathrm{ml}$ purified FMDV samples while detect limit of conventional ELISA is $100 \mathrm{ng} / \mathrm{ml}$ in this study. The detect limit of this study was lower than the theoretical detect limit. This may be due to the influence of some factors, for example, the combination efficiency of the monoclonal antibody, the captured efficiency of the antigen, or the sample contamination [34]. Meanwhile, the results of detection clinical FMDV samples indicated that GNP-IPCR assay is suitable for clinical diagnosis and surveillance of FMDV. To our knowledge, this is the first report that GNP-PCR was applied in the detection of FMDV antigen.

Table 2 Evaluation of 85 clinical samples by GNP-IPCR

\begin{tabular}{ccc}
\hline Specimen & $\begin{array}{c}\text { Sample } \\
\text { No. }\end{array}$ & $\begin{array}{c}\text { No. (\%) of positive samples by } \\
\text { GNP-ELISA }\end{array}$ \\
\hline Serum of type O & 30 & $30(100)$ \\
Vesicle fluid of type & 20 & $20(100)$ \\
O & & $0(0)$ \\
Serum of type Asia 1 & 6 & $0(0)$ \\
Vesicle fluid of type & 4 & $1(3.4)$ \\
Asia1 & & \\
Negative serum & 26 & \\
\hline
\end{tabular}

\section{Acknowledgements}

This work was supported in parts by grants from National Key Technologies R\&D Program (2009ZX08007-006B), International Science \& Technology Cooperation Program of China (No.2010DFA32640) and Science and Technology Key Project of Gansu Province (No.0801NKDA034). This study was also supported by National Natural Science foundation of China (No.30700597 and No. 31072143).

\section{Author details}

${ }^{1}$ State Key Laboratory of Veterinary Etiological Biology, Key Laboratory of Animal Virology of Ministry of Agriculture, Lanzhou Veterinary Research Institute, Chinese Academy of Agricultural Sciences, Lanzhou, 730046, Gansu, China. ${ }^{2}$ lanzhou Jiaotong Univesity Bowen College, Lanzhou, 730101, Gansu, China.

\section{Authors' contributions}

$J Z, Y D$ and $Y L$ designed the study and drafted the manuscript. JZ, HC, GW and LM prepared the monoclonal antibodies and performed GNP-IPCR. All authors read and approved the final manuscript.

\section{Competing interests}

The authors declare that they have no competing interests.

Received: 6 December 2010 Accepted: 31 March 2011

Published: 31 March 2011

\section{References}

1. Knowles NJ, Samuel AR: Molcular epidemiology of foot-and- mouth disease virus. Virus Res 2003, 91:65-80.

2. Robson $\mathrm{KJH}$, Harris TJR, Brown F: An assessment by competition hybridisation of the sequence homology between the RNAs of the seven serotypes of FMDV. J Gen Virol 1977, 37:271-276.

3. Davies G: The foot and mouth disease(FMD) epidemic in the United Kingdom 2001. J Comp Immunol Microbiol Infect Dis 2002, 25:331-343.

4. Thomson GR, Vosloo W, Bastos ADS: Foot-and-mouth disease in wildlife. Virus Res 2003, 91:145-161.

5. Alexandersen S, Zhang Z, Donaldson Al, Garland AJ: The pathogenesis and diagnosis of foot-and-mouth disease. J Comp Pathol 2003, 129:1-36.

6. Verheyden B, Lauwers S, Rombaut B: Quantitative RT-PCR ELISA to determine the amount and ratio of positive- and negative-strand viral RNA synthesis and the effect of guanidine in poliovirus infected cells. $J$ Pharm Biomed Anal 2003, 33:303-308. 
7. Moss A, Hass B: Comparison of the plaque test and reverse transcription nested PCR for detection of FMDV in nasal swabs and probing samples. J Virol Methods 1999, 80:59-67.

8. Callahan JD, Brown F, Osorio FA, Sur JH, Kramer E, Long GW, Lubroth J, Ellis SJ, Shoulars KS, Gaffney KL, Rock DL, Nelson WM: Use of a portable real-time reverse transcriptase-polymerase chain reaction assay for rapid detection of foot-and-mouth disease virus. J Am Vet Med Assoc 2002, 220:1636-1642

9. King DP, Ferris NP, Shaw AE, Reid SM, Hutchings GH, Giuffre AC, Robida JM, Callahan JD, Nelson WM, Beckham TR: Detection of foot-and-mouth disease virus: comparative diagnostic sensitivity of two independent real-time reverse transcription-polymerase chain reaction assays. Journal of Veterinary Diagnostic Investigation 2006, 18:93-97.

10. Gu C, Zheng C, Shi L, Zhang Q, Li Y, Lu B, Xiong Y, Qu S, Shao J, Chang H: Plus- and minus-stranded foot-and-mouth disease virus RNA quantified simultaneously using a novel real-time RT-PCR. Virus Genes 2007, 34:2461-2469.

11. Fosgate GT, Tavornpanich S, Hunter D, Pugh R, Sterle JA, Schumann KR, Eberling AJ, Beckham TR, Martin BM, Clarke NP, Adams LG: Diagnostic specificity of a real-time RT-PCR in cattle for foot-and-mouth disease and swine for foot-and-mouth disease and classical swine fever based on non-invasive specimen collection. Vet 2008, 132:158-164.

12. Nunez JI, Blanco E, Hernandez T, Gomez-Tejedor C, Martin MJ, Dopazo J, Sobrino F: A RT-PCR assay for the differential diagnosis of vesicular viral diseases of swine. J Virol Meth 1998, 72:227-235.

13. Lomakina NF, Fallacara F, Pacciarini M, Amadori M, Lomakin Al, Timina AM, Shcherbakova LO, Drygin W: Application of universal primers for identification of foot-and-mouth disease virus and swine vesicular disease virus by PCR and PCR-ELISA. Arch Virol 2004, 149:1155-1170.

14. Reid SM, Hutchings GH, Ferris NP, De Clercq K: Diagnosis of foot-andmouth disease by RT-PCR: evaluation of primers for serotypic characterisation of viral RNA in clinical samples. J Virol Meth 1999, 83:113-123.

15. Nam JM, Thaxton CS, Mirkin CA: Nanoparticle-based bio-bar codes for the ultrasensitive detection of proteins. Science 2003, 301:1884.

16. Bao YP, Wei TF, Lefebvre A, An H, He L, Kunkel GT, Muller UR: Detection of protein analytes via nanoparticle-based bio bar code technology. Anal Chem 2006, 78:2055.

17. Stoeva SI, Lee JS, Smith JE, Rosen ST, Mirkin CA: Multiplexed detection of protein cancer markers with biobarcoded nanoparticle probes. J Am Chem Soc 2006, 128:8378.

18. Wang $X S$, Sun $Y$, Jing $S, M a X M$, Zeng $Y$ : Combining gold nanoparticles with real-time immuno-PCR for analysis of HIV p24 antigens. Bioinformatics and Biomedical Engineering. ICBBE 2007, The 1st International Conference on: 1198

19. Chen LY, Wei HP, Guo YC, Cui ZQ, Zhang ZP, Zhang XE: Gold nanoparticle enhanced immuno-PCR for ultrasensitive detection of Hantaan virus nucleocapsid protein. Journal of immunological methods 2009, 346:64-70.

20. Roeder PL, Le Blanc Smith PM: Detection and typing of foot-and-mouth disease virus by enzyme-linked immunosorbent assay: a sensitive, rapid and reliable technique for primary diagnosis. Research in Veterinary Science 1987, 43:225-232.

21. Saiki RK, Scharf S, Faloona F, Mullis KB, Horn GT, Erlich HA, Arnheim N: Enzymatic amplification of beta-globin genomic sequences and restriction site analysis for diagnosis of sickle cell anemia. Science 1985, 230:1350-1354.

22. Laor $\mathrm{O}$, Torgersen $\mathrm{H}$, Yadin $\mathrm{H}$, Becker Y: Detection of FMDV RNA amplified by the polymerase chain reaction (PCR). Journal of Virological Methods 1992, 36:197-207.

23. Oleksiewicz MB, Donaldson Al, Alexandersen S: Development of a novel real-time RT-PCR assay for quantitation of foot-and-mouth disease virus in diverse porcine tissues. Journal of Virological Methods 2001, 92:23-35.

24. Bao HF, Li D, Guo JH, Lu ZJ, Chen YL, Liu ZX, Liu X T, Xie QG: A highly sensitive and specific multiplex RT-PCR to detect foot-and-mouth disease virus in tissue and food samples. Arch Virol 2008, 153:205-209.

25. Huang X, Li Y, Zheng CY: A novel single-cell quantitative real-time RTPCR method for quantifying foot-and-mouth disease viral RNA. Journal of Virological Methods 2009, 155:150-156.

26. Sano T, Smith CL, Cantor CR: Immuno -PCR: very sensitive antigen detection by means of specific conjugates. Science 1992, 258:120-122.
27. Danied MC, Astruc D: Gold nanoparticles: assembly, supram- olecular chemistry, quantum-size-related properties, and applications toward biology, catalysis, and nanotechnology. Chem Rev 2004, 104:293-346.

28. Elghanian R, Storhoff JJ, Mucic RC, Letsinger RL, Mirkin CA: Selective colorimetric detection of polynucleotides based on the distancedependent optical properties of gold nanoparticles. Science 1997, 277:1078-1080

29. Mirkin CA, Letsinger RL, Mucic RC, Storhoff JJ: A DNA-based method ofr rationally assembling nanoparticles into macroscopic materials. Nature 1996, 382:607-609

30. Parak WJ, Gerion D, Pellegrino : Biological applications of colloidal nanocrystal. Nanotechnology 2003, 14:15-27.

31. Kim EY, Stanton J, Vega RA, Kunstman KJ, Mirkin CA, Wolinsky SM: A realtime PCR-based method for determining the surface coverage of thiolcapped oligonucleotides bound onto gold nanoparticles. Nucleic Acids Res 2006, 34:e54.

32. Chen HY, Zhuang HS: Real-time immuno-PCR assay for detecting PCBs in soil samples. Anal Bioanal Chem 2009, 394:1205-1211.

33. Roth L, Zagon J, Ehlers A, Kroh LW, Broll H: A novel approach for the detection of DNA using immobilized peptide nucleic acid (PDA) probes and signal enhancement by realtime immuno polymerase chain reaction (RT-iPCR). Anal Bioanal Chem 2009, 394:529-537.

34. Niemeyer CM, Adler M, Wacker R: Detecting antigens by quantitative immuno-PCR. Natl Protoc 2007, 2:1918-1930.

doi:10.1186/1743-422X-8-148

Cite this article as: Ding et al:: A highly sensitive detection for foot-andmouth disease virus by gold nanopariticle improved immuno-PCR. Virology Journal 2011 8:148.

\section{Submit your next manuscript to BioMed Central and take full advantage of:}

- Convenient online submission

- Thorough peer review

- No space constraints or color figure charges

- Immediate publication on acceptance

- Inclusion in PubMed, CAS, Scopus and Google Scholar

- Research which is freely available for redistribution

Submit your manuscript at www.biomedcentral.com/submit
Ciomed Central 